\title{
Review
}

\section{The Intellectual Domains of Sustainability Leadership in SMEs}

\author{
Jane Boeske* and Peter A. Murray
}

School of Business, University of Southern Queensland, Toowoomba 4350, Australia; Peter.Murray@usq.edu.au * Correspondence: Jane.Boeske@usq.edu.au; Tel.: +61-7-46315496

Citation: Boeske, J.; Murray, P.A. The Intellectual Domains of Sustainability Leadership in SMEs. Sustainability 2022, 14, 1978. https://doi.org/ $10.3390 /$ su14041978

Academic Editor: Huseyin Arasli

Received: 2 November 2021

Accepted: 25 January 2022

Published: 9 February 2022

Publisher's Note: MDPI stays neutral with regard to jurisdictional claims in published maps and institutional affiliations.

Copyright: (c) 2022 by the authors. Licensee MDPI, Basel, Switzerland. This article is an open access article distributed under the terms and conditions of the Creative Commons Attribution (CC BY) license (https:// creativecommons.org/licenses/by/ $4.0 /)$.

\begin{abstract}
The goal of this paper is to review the intertwined range of conceptualizations that have blurred developing leadership knowledge regarding environmental sustainability. An examination of the leadership literature reveals differential descriptions about sustainable, environmental, and sustainability leadership which are increasingly being used to imply what sustainability-focused leaders do, their interactions, their relationships, and how they address sustainable challenges. While extant research supports that leadership is a critical capability to respond and adapt to constant external environmental and economic upheaval in large firms, agreement about the types of leadership practices necessary to achieve positive environmental sustainability and eco-efficient outcomes is less clear in Small and Medium Enterprises (SMEs). To resolve these problems, we synthesize the sustainable, environmental and sustainability leadership literature by (a) reviewing and clarifying these leadership constructs, (b) theoretically unravelling these overlapping concepts, and (c) developing an integrated framework of intellectual capital and sustainability leadership practices. From a theoretical perspective, this paper seeks to make a significant contribution to the scholarly leadership literature by offering several leadership classifications of skills and knowledge relevant to leadership knowledge domains. Given that extant research has conflated many leadership approaches, this paper builds on the theoretical knowledge of the kind of leadership skills required for sustainability leadership. From a practical perspective, we provide SME leaders with knowledge about the types of leadership practices, behaviours, and activities that will enhance sustainable productivity in their firms. The paper is designed to advance a new way of thinking about existing sustainability leadership by presenting an original contribution that alters and reorganizes potential causal maps, that are potentially more valuable. Whilst most of the leadership research involves large firms, we seek to better understand and inform sustainability leadership in SMEs.
\end{abstract}

Keywords: sustainable; environmental and sustainability leadership; organization capital; network capital; sustainable productivity; eco-efficient outcomes; intellectual capital; small and medium enterprises (SMEs)

\section{Introduction}

Research on sustainability leadership in SMEs is important as there is a growing awareness within the SME literature that traditional operating procedures incurring high energy and water consumption costs, minimal recycling, and generation of considerable waste (among others) are no longer sustainable [1,2]. More than 70 years ago, Stogdill [3] noted that the study of leadership is an analysis of relationships and that all organizations operate within a large cultural and environmental framework. The objectives of organizations should be to maximise social values relative to the limited resources available [3,4]. For contemporary scholars, there is increasing interest and strategic concern to reduce and recycle waste, use less energy and water, develop new products or services, and to create efficiencies and increase innovation $[5,6]$. SME leaders are in a powerful position to promote positive environmental sustainability and eco-efficient outcomes in their firms. Indeed, leaders and leadership are a 'key interpreter' of how organizations respond to environmental challenges [7]. Although there is an emerging leadership literature describing sustainable, environmental and sustainability leadership in the education 
sector [8,9], large companies [10-12], and government [13], many extant studies only take the narrative related to SME sustainability leadership so far. Whilst leadership is considered an important capability to respond and adapt to external environmental and economic fluctuations [14], there is a lack of agreement and understanding about the types of leadership necessary for positive environmental sustainability $[7,15,16]$. What is missing in leadership literature is a theoretical framework that provides a new way of thinking about existing sustainability leadership dimensions. This is important in the study of sustainability leadership since scholars and practitioners are often no wiser about which leadership behaviours best suit eco-efficient outcomes and sustainable practices. It is particularly important for SME leaders who lack the necessary knowledge, capital, and resources to address and implement sustainability initiatives $[17,18]$. Thus, the aim of this paper is to classify the emerging leadership skills and knowledge necessary to achieve improved SME environmental performance.

While the sustainability literature is one of the most interesting fields of scholarly inquiry related to achieving eco-efficient outcomes, specific knowledge about sustainability leadership practices and skills is not well defined across industry settings and within knowledge domains [12,19]. General descriptions about sustainable, environmental, and sustainability leadership are increasingly being used to imply what sustainability-focused leaders do, their interactions, their relationships, and how they address complex sustainable challenges, even while the contexts in which leaders operate are difficult and complex $[20,21]$. While leadership is considered an important capability to respond and adapt to external environmental and economic fluctuations [14,22], agreement about the types of leadership practices necessary to achieve positive environmental sustainability is less transparent $[7,12,16]$. Scholars note that sustainability challenges require new leadership skills and practices that 'help support managers to become effective sustainability leaders in their organizations' [12]. Accordingly, this review seeks to expand relative scientific contribution by drawing upon a range of theoretical ideas, and the most pervasive leadership skills and practices relevant within a leadership domain. Here, the review is designed to provide more revelatory value by improving the classification and compilation of leadership skills and behaviours by elevating their utility within an SME context.

While extant studies examining leader practices have been linked to sustainability $[7,23]$, environmental leadership practice [24], and sustainable productivity outcomes [10,22,24], few clear links exist between leadership practice cause and effect in respect of sustainable outcomes more generally. Thus far, scholars use sustainable, environmental, and sustainability terminologies interchangeably, yet this often creates confusion in the literature, making it more difficult for scholars and practitioners to identify which sustainability leadership practices are more germane within a given context $[20,25,26]$. In order to make sense of the literature and to clarify often contradictory terms, this paper offers a framework that provides a nuanced understanding of the practices relating to sustainability leadership.

Different leadership practices do not only reflect individual-level leadership attributes, but also organization-level practices embedded as structures, systems, and routines as mechanisms to create change. A typical example of structures and systems is sustainable production processes to reduce waste or technological structures to reduce emissions. These structures potentially create innovation $[27,28]$. Organizations design structures and systems to create institutional knowledge that increases the organizational capacity $[29,30]$ of leaders to respond to environmental challenges necessary to guide how the organization itself learns [31,32], including knowledge about how different aspects of organization design have an important mediating influence on environmental management [33]. As an organization-level attribute, sustainable structures and systems will need to reflect what leaders pay attention to [34], including the routines that are created that lead to sustainable knowledge creation $[35,36]$. Within the existing literature on sustainability leadership, it is less clear how these structures and systems are created to support sustainable innovations in general. 
Similarly, how SMEs introduce sustainability measures by creating strong internal and external network capital linkages needs to be better understood [37]. Social capital buttresses the development of social relationships [38], where social relationships comprise of both internal and external social capital that provide linkages between individuals and external firms [39]. Social capital more generally refers to the 'ability of actors to secure benefits by virtue of membership in social networks or other social structures' [40]. External relationships refer to networks established among external actors [38,41,42], that together lead to network capital benefits such as co-created knowledge routines through leadership experience ties $[43,44]$. This involves an affinity between individual and organization-level leadership attributes with a priority to establish social, as well as organization capital $[39,45]$. Since sustainability is concerned about the impact of decisions on the natural environment, leaders need to work more closely within and across networks.

A more 'tightly coupled' and relational link between the organization and the natural world [46] will become increasingly important through the establishment of social networks. However, the role that social relationships play in SMEs is not clearly defined in extant studies. Given the importance of matching leadership practices to sustainability challenges that comprise a combination of leader practices, structures and systems, and social capital priorities, this review paper explores which practices better support sustainable productivity and eco-efficient outcomes in SMEs. We contend that three intellectual domains of intellectual knowledge underpin these narratives: (1) leadership capital, (2) organization capital, and (3) network capital.

In addition to the classification of leadership skills and knowledge relevant to developing sustainable productivity as a primary goal of this paper, a secondary goal is to analyze which SME structures, systems, and routines help build sustainable outcomes, as well as how network capital shapes social relationship practices. Taken together, this paper seeks to make a significant contribution to the scholarly sustainability leadership literature by developing a more nuanced and integrated theoretical framework of intellectual capital and sustainability leadership practices (discussed next). We provide a new way of thinking about existing leadership dimensions within the sustainability literature by offering a new classification of leadership practices and skills that advances existing knowledge.

The paper is structured as follows. First, we analyze the relationship between sustainable, environmental, and sustainability leadership practices and synthesize their integrative features. Second, we review how organizational capital supports sustainable organization practices. Third, network capital is explored through the lens of social relationship practices. Fourth, we outline how the integrative practices of intellectual capital create the strategies that support increases in sustainable productivity and eco-efficiency outcomes. Finally, a discussion of the main contributions of the paper is outlined, together with the limitations of the research.

\section{Sustainable, Environmental and Sustainability Leadership}

There is a significant body of literature related to the functions of sustainable, environmental, and sustainability leadership over the last 30 years. Extant research treats these as separate bodies of literature, yet while the embodiment of functions and processes could be deemed as dissimilar, fine nuances and complementary characteristics exist with respect to leadership practices. Sustainable leadership (SL) is often described in terms of being socially and environmentally responsible, preserving and sustaining the environment, and as a shared responsibility between both internal and external players as they plan for long-term sustainable goals $[4,10,23]$. Similarly, environmental leadership (EL) relies on practices that care for and protect the natural environment such as the deep-seated values and beliefs of organizations and the moral commitment of its members towards achieving a sustainable outcome [22,47]. Slightly different is sustainability leadership (ST-L). Here, it is about anyone who takes responsibility for acting on sustainable challenges including but not limited to initiating and influencing change towards some sustainable future $[16,48]$. Similarly, for ST-L, setting direction while simultaneously creating organizational alignment 
underpins a commitment towards employee and stakeholder buy-in [49]. Interestingly, leadership practice becomes critical for SL, EL, and ST-L practices, such as establishing a creative culture that enables the organization to learn new things and increase its innovative processes $[7,25]$.

Leadership practices more generally underpin the nuanced differences between the three definitions. At their most basic, leadership practices involve key knowledge, skills, and abilities that comprise the individual-level attributes of individual leaders [50-52]. First, practices related to developing SL skills pertains to the cognitive antecedents of leaders, namely establishing a mindset for innovation, creating shared responsibility and passion between stakeholders, and developing the motivation towards achieving sustainable goals [8-10,53]. We call these innovation and relational practices. Second, practices related to EL pertains to an embedded personal moral imperative towards protecting the environment, identifying individual and organizational levels of influence, and establishing a set of sustainable personal values and norms $[24,47,53,54]$. We call these ideological and moral practices. Lastly, practices related to ST-L pertain to what leaders do in relation to direction-setting and top management commitment, relational-oriented practices, and task-oriented practices towards developing action plans, aligning goals, and dealing with complex internal and external environmental adaptation $[52,55,56]$. We call these strategic adaptation practices.

In sum, these leadership practices underpin what leaders do, the tasks and functions that guide action to build environmentally sustainable outcomes (ESO) within the SME context and form the basis of the theoretical framework (Figure 1). What is illustrated in Figure 1 is that leadership capital does not stand in isolation of other sustainable knowledge practices, which are explained in more detail later in this review paper. Our research suggests that leadership will occur not only at the individual level but will necessitate integration with sustainable practices at the organization and network capital level. For instance, sharing positive change and building environmental norms will almost certainly be fashioned at the organizational level [57], while mobilizing employees is not only an individual skill but also an organizational process that helps establish long-term ecological goals [58]. Similarly, the idea of co-creation within the sustainability literature involves moving beyond individual social relations to forging value-chain based production processes [35], as well as the self-development of actors (SME Leaders) networking, collaborating, and forming ecosystems that support sustainable productivity goals [59]. Co-creation itself appears to invoke a set of leadership practices focused on the creation of an integrated network of suppliers, vendors, and customers [49]. In sum, the theoretical framework is a new approach aimed at bringing to the forefront many leadership skills and practices in SMEs.

For the first of the sustainable knowledge practices presented in Figure 1, the separate but related bodies of sustainable and environmental leadership practice are transitioned into one generic term, that is, sustainability leadership (ST-L hereafter). This review thus seeks to address what studies appear to describe as separate leadership practices by clarifying that, collectively, such practices are complementary and integrated individuallevel leadership attributes. This is similar to how complementarity is described within the human capital resource (HCR) literature, where an 'employee and the firm possess distinct HCR that, when combined, have the potential to create an amount of value that is greater than the sum of the individual parts' [60]. 


\section{Intellectual Domains of Sustainable Knowledge Practices}

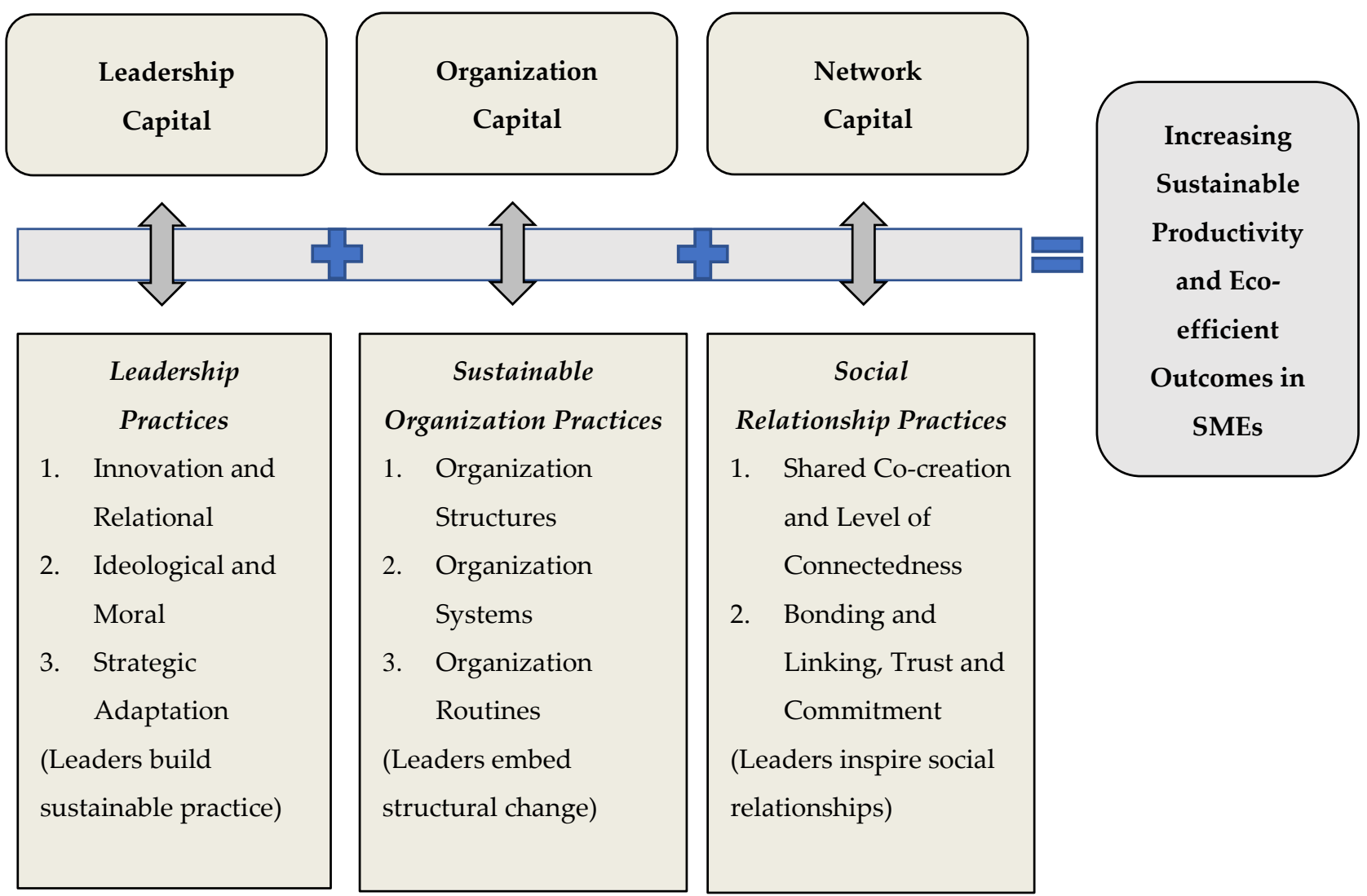

Figure 1. An intellectual capital framework of sustainability leadership in SMEs. Source: Authors.

While nuanced differences can be observed in the three approaches, it makes little sense to separate the practices of leaders across similar sustainability tasks. Thus, we provide greater clarity of the relationship between ST-L and how to achieve environmentally sustainable and eco-efficient outcomes based on what leaders do by exploring which leadership practices are more germane within a given ST-L context. Accordingly, ST-L is the basis of leadership practices (see Figure 1) and is discussed in more detail next. An analysis and summary of extant research that informs the relationships in Figure 1 is outlined in Table 1 as follows. 
Table 1. Summary of extant research in intellectual domains of sustainable knowledge practices.

\begin{tabular}{|c|c|c|c|}
\hline \multicolumn{4}{|c|}{ Leadership Capital-Leadership Practices } \\
\hline & Emerging Concepts & References & Summary of Key Findings \\
\hline 1. & $\begin{array}{l}\text { Innovation and Relational } \\
\text { Leadership Practices }\end{array}$ & $\begin{array}{l}\text { Burns, 1978; Yukl et al., 2002; Hargreaves and } \\
\text { Fink, 2006; Ferdig, 2007; Crews, 2010; Avery and } \\
\text { Bergsteiner, 2011; Wang et al., 2011; Tildeman } \\
\text { et al., 2013; McCann and Sweet, 2014; Burns } \\
\text { et al., 2015; Behrendt et al., 2017; Jang et al., } \\
\text { 2017; Robertson and Barling, 2017; Robertson } \\
\text { and Carleton, 2018; Yukl et al., 2019; Fry and } \\
\text { Engel, 2021. Prasanna et al., 2021. }\end{array}$ & $\begin{array}{l}\text { - Components of transformational leadership are most effective to promote sustainability and is a } \\
\text { shared responsibility } \\
\text { Requires a long-term perspective in decision making fostering innovation and building continuous } \\
\text { improvement, creation of opportunities for people to come together to generate their own answers } \\
\text { - An integrated effort that requires communication among various stakeholders, collaboration, } \\
\text { inclusiveness, relationships, and common purpose are components in engaging pro-environmental } \\
\text { behaviours, commitment towards a more balanced approach considering the triple bottom line, } \\
\text { motivation, and extraordinary decision making and problem-solving skills are required } \\
\text { Leaders concerned with people and the environment will support stakeholders that represent the } \\
\text { best interests of people and the planet }\end{array}$ \\
\hline 2. & $\begin{array}{l}\text { Ideological and Moral } \\
\text { Leadership Practices }\end{array}$ & $\begin{array}{l}\text { Shamir et al., 1993; Egri and Frost, 1994; } \\
\text { Flannery and May, 1994; Robinson and Clegg, } \\
\text { 1998; Conger, 1999; Hargreaves and Fink, 2006; } \\
\text { Svensson and Wood, 2007; Egri and Herman, } \\
\text { 2000; Boiral et al., 2014; Deinert et al., 2015; } \\
\text { Burns et al., 2015; Tajason et al., 2015; Adams } \\
\text { et al., 2016; Jang et al., 2017; Vasquez et al., 2019. }\end{array}$ & $\begin{array}{l}\text { - Sustainability leadership is founded on a moral purpose, are more aware of eco-centric values, } \\
\text { develop an ecological vision and are personally committed to reduce or prevent pollution } \\
\text { - } \quad \text { Moral norms, values and environmental attitudes are factors influencing top managers } \\
\text { - } \quad \text { Strategies devised that improve competitive advantage about caring for the environment } \\
\text { - } \quad \text { Leadership ethics is a continual and iterative process and personal values are strongly concerned } \\
\text { with the welfare of others and the environment }\end{array}$ \\
\hline 3. & $\begin{array}{l}\text { Strategic Adaption } \\
\text { Leadership Practices }\end{array}$ & $\begin{array}{l}\text { Boal and Hooijberg, 2000; Van Velsor and } \\
\text { McCauley, 2004; Jansen et al., 2009; Quinn and } \\
\text { Dalton, 2009; Battilana et al., 2010; Hsu and } \\
\text { Wang, 2012; Adams et al., 2016; Arnold, 2017; } \\
\text { Carro-Suarez et al., 2017; Kurucz et al., 2017; } \\
\text { Nui et al., 2018; Vasquez et al., 2019; } \\
\text { Yukl et al., 2019. }\end{array}$ & $\begin{array}{l}\text { - Transformational and relational, transactional and task leadership and change leadership } \\
\text { behaviours are important strategic leadership practices for pro-environmental initiatives, and are } \\
\text { related to managerial effectiveness and strategic sustainability } \\
\text { Tasks such as setting direction, creating alignment, and maintaining commitment are required, as } \\
\text { well as developing actions plans, communicating, making decisions and solving problems, } \\
\text { deploying resources, and driving change that requires action to be taken on sustainability values. } \\
\text { Making intentional changes to an organization's mission and values leads to changed products, } \\
\text { processes or practices that create environmental value } \\
\text { - Co-creation is a way of sharing, combining and renewing resources, knowledge and ideas to create } \\
\text { value through new forms of interaction, service and learning } \\
\text { - Sustainability strategies and environmental practices help to decrease their negative impact and } \\
\text { promote cost effectiveness }\end{array}$ \\
\hline
\end{tabular}


Table 1. Cont.

\section{Organization Capital—Sustainable Organizational Practice}

\section{Emerging Concepts}

References

\section{Summary of Key Findings}

Cohen and Levinthal, 1990; Helfat, 1997; Robinson and Clegg, 1998; Johnson, 1999; Bontis and Fitz-enz, 2002; Zahra and George, 2002; Marr, 2004; Youndt, 2005; Cohen and Kaimenakis, 2007; Ferdig, 2007; Timmer et al. 2007; Epstein, 2008; Stahle, 2008; Quinn and Dalton, 2009; Crews, 2010; Epstein et al., 2010; Clarke et al., 2011; Arora and Nandkumar, 2012 Hsu and Wang, 2012; Tideman et al., 2013; Benn et al., 2014; Hu and Randel, 2014; Murray, 2018; Pertusa-Ortega et al., 2018; Yukl et al., 2019;

Kantabutra, 2020.

. Organization Systems

Organization Routine

Network Capital-Social Relationship Practices

\section{Emerging Concepts}

7. Shared Co-creation an Level of Connectedness 8. Bonding and Linking, Trust and Commitment

\section{References}

Baker, 1990; Flannery and May, 1994; Coleman 1988; Robinson and Clegg, 1998; Johnson, 1999 Bontis and Fitz-end, 2002; Adler and Kwon, 2002; Boiral et al., 2009; Quinn and Dalton, 2009; Crews, 2010; Manning, 2010; Avery and Bergsteiner, 2011; Clarke et al., 2011; Hsu and Wang, 2012; Tideman et al., 2013; Benn et al. 2014; Boiral et al., 2014; Costa et al., 2014; Whipple et al., 2015; Arnold, 2017; Etzion et al., 2017; Jang et al., 2017; Behrendt et al., 2017; Pillai et al., 2017; Bontis et al., 2018; Wang and Cotton, 2018; Burlea-Schiopoiu and Mihai (2019); Redondo and Camerero, 2019; Haney et al., 2020; Fry and Egel, 2021;

Tolstykh et al., 2021
Creation of structures that support the vision and mission of sustainability

Embedding sustainability in business structures by establishing policies, procedures and innovative organizational designs-including effective team structures

Commitment, communication (including speeding the flow of knowledge routines), organization, control and monitoring (continuous improvement and planning are essential) in managing and reporting sustainable productivity

Leaders must pay attention to regulations, legal obligations, and shareholder activism

The importance of soft/informal systems and processes are just as important as formal systems that measure and reward performance towards sustainable productivity goals

Goal clarity, delegating, and the ability to monitor and evaluate eco-efficient change processes

\section{Summary of Key Findings}

- Teamwork (including employee contributions) and an ability to mobilise employees around long-term ecological goals, thus developing co-creation of ideas

Focus on stakeholder engagement and creating a culture that is integrated resulting in a sharing approach

- Building strong social relationships (both internal and external) and recognising interdependence, interconnectedness, continuity and common purpose of all stakeholders both long and short-term influencing and collaborating, building trust and establishing fairness

Developing an understanding, personal connection and empowerment to act for sustainability

Learning, lobbying, and forming alliances with a focus on communication

Application of an ecosystem model that makes it possible to form a friendly environment where the goals of all stakeholders aiming to achieve sustainable productivity are harmonised 


\section{Conceptualizing the Intellectual Domains of Sustainable Capital}

\subsection{Individual-Level Leadership Practices}

Leadership Capital in Figure 1 is underlined by three individual-level practices: (1) innovation and relational, (2) ideological and moral, and (3) strategic leadership adaptation. Aspects of innovation and relational practices relate to what leaders do to identify the shared responsibility roles between various stakeholders $[9,10]$. For instance, Tideman et al. [23] notes the importance of influencing, collaboration, trust and fairness between all stakeholders that create opportunities to generate sustainable and innovative solutions $[25,58]$. Fry and Egel [53] take this one step further and argue that leaders move beyond satisfying stakeholder demands to include a more balanced sustainable approach which is focused on the triple bottom line. ST-L leaders who base their leadership styles on individual relational skills closely correlates with relational leadership theory $[61,62]$. Here, the relational attributes of the leader create a strong vision by developing a strategic perspective. Leaders work on developing their own personal inspiration, instil the capacity to innovate and be creative, provide intellectual stimulation and risk taking, and demonstrate strong personal values $[16,63,64]$. We suggest that given the SME context, a highly participative process will be common. Similarly, ST-L leaders create opportunities for people to work collaboratively and generate their own answers to sustainability challenges specific to their context, modifying and adapting these responses to changing circumstances [16]. Innovational and relational practices involve coaching, guiding, and supporting individuals [65] in developing leadership capabilities similar to the way that transformational leaders influence employees' self-concept. According to scholars, relational leaders share environmental values that inspire and motivate employees to think about sustainability issues in new and innovative ways [66], which results in increases in individual, team, and organizational performance $[11,25,58]$.

Similarly, being innovative and relational requires continuous improvement skills to remain competitive. Here, ST-L is an iterative process that is highly dynamic and innovative as creative ways are needed to solve problems and improve motivation towards sustainable productivity $[23,24,67]$. The innovation and relational practices invoke socially and environmentally responsible ideas [10]. Leaders here are concerned about protecting the environment $[9,47]$, considering the triple bottom line perspective of caring for people, planet and profits [4], and developing business objectives that promote eco-efficiency [23], by adopting a cost leadership and cost focus approach $[24,67]$. Thus, innovation and relational practices accentuate what leaders do to enhance sustainable productivity [10]. These practices closely mirror what Yukl et al. [50] suggest are relations-oriented practices because the key task of the leader is to maintain subordinate task commitment, confidence, and cooperation (see Table 1). In sum, while a plethora of studies highlight different leadership skills, the emergent themes related to these have thus far been one-off recommendations. Thus, it has been very difficult for scholars and practitioners to establish which leadership skills relate to a specific knowledge domain. Here, Table 1 classifies these skills according to the review conducted which enable scholars to identify the innovative and relational skills required within each emergent theme. Next, this review argues that leaders also take on an ideological and moral perspective when implementing sustainable productivity and eco-efficient outcomes in their firms.

ST-L depends on ideological and moral practices as well. For instance, several studies acknowledge the importance of moral norms [64,68,69], and the notion of personal values and how these contribute to the welfare of others and the environment [57]. Leaders need to be ethical and meaningful to bring about positive change, although not all ST-L leaders share the same values or have the same way of managing environmental issues [22,26]. Organizational members morally committing to an environmentally sustainable planet invokes moral considerations [9]. Several scholars contend that taking action on sustainability values is about taking steps to mobilize employees around long-term ecological goals $[58,70,71]$, and eco-efficiency principles [72] similar to the way transformational leaders mobilize the efforts of their workers towards a long-term goal. For instance, personality 
traits that stimulate followers to think out of the box-such as openness to experienceare more strongly related to the intellectual stimulation of the leader, whereas traits that promote leaders' caring behaviour-such as agreeableness-are likely to predict individualized consideration more strongly [73]. Similarly, Shamir et al. [74] suggest that leaders influence the self-concept of their followers by associating followers' goals and collective experiences to the leader's mission so that 'they become valued aspects of the followers' self-concept [75]. Here, we contend that the ideological and moral practices of ST-L leaders will mirror those of transformational leaders in normal organization settings, reflecting the moral norms and personal values that drive sustainable ideas.

Boiral et al. [22] suggests that environmental commitment is a proactive stance taken by leaders applying a top-down approach towards sustainable outcomes. Organization-level practices underpin sustainable goals since environmental concerns are both scientifically and socially complex $[22,66]$. Organizations need to demonstrate how they care for and protect the natural environment, and how waste and eco-efficient/innovation strategies go further than prescribed legislative requirements $[68,69,76]$. Overall, the main concepts of ideological and moral practices relate to the values that drive sustainable ideas and beliefs (see Table 1). These practices work in tandem with strategic leadership adaptation (discussed next).

Strategic leadership adaptation (see Figure 1) by comparison relates to managing resources and capabilities that align with organizational goals, thus enhancing an organization's long-term success [77,78]. As Hsu and Wang [45], contend, managers are required to deploy resources to implement competitive strategies and have the ability to drive change and innovation which requires action to be taken on sustainability values by developing action plans [70] that reflect these values. Niu et al. [24] suggest that change oriented transformational leadership behaviours are fundamental in achieving pro-environmental initiatives.

Extant scholars suggest that task-oriented leadership underscores sustainability processes $[35,50,79]$. Task leadership competencies include planning for contingencies, communicating, mobilizing action in the direction of established goals, and coordinating and monitoring activities and problem solving $[50,80]$ that address deep-seated sustainability issues. Here, leadership is concerned with the evolution of the organization and its changing aims and capabilities-leadership is a series of decisions and activities, both process-oriented and substantive in nature [81]. Features of task leadership are highlighted in Quinn and Dalton's [49] qualitative study where the principles, strategies, policies, and practices of sustainability reflected the actions of senior leaders. They emphasize that tasks were reflective of (1) setting direction, (2) creating alignment, and (3) maintaining commitment, as leader's reformed, restructured, and redesigned their strategies towards sustainable goals [49]. For instance, environmental management systems that enable the efficient use of materials to reduce environmental impacts and risks closely resembles creating an alignment between eco-efficiency strategies and sustainable goals [72]. Similarly, given that SMEs more generally relate to a heterogenous group, both internal and external processes need to be tied to sustainable knowledge practices because knowledge of these practices is critical [82]. Because of the task orientation and participatory requirements of leading SME firms, we contend that strategic adaptation practices closely follow what Yukl et al. [50] suggest is task-oriented practice. Thus, what leaders do in this context is specific to the sustainability task at hand. This involves planning work unit activities, enabling problem solving opportunities, monitoring operations and clarifying sustainable roles and performance (see Table 1).

Moreover, the strategic adaptation phase will need to be more granular in terms of facilitating implementation plans that incorporate routines and newly acquired sustainable behaviours, as well as clarifying how to develop eco-innovative resources required for successful implementation [65]. Taken together, complementary ST-L leadership practices are required to achieve ST-L change leading to proposition 1. Next, we explore how 
organizational capital provides the capabilities required for an organization to change over time.

Proposition 1. ST-L leadership is a complimentary process of combining innovation, relational, ideological, moral, and strategic adaptation leadership practices.

\subsection{Organization Capital—Structures, Systems and Routines}

Organization capital (OC) in Figure 1 is underlined by three organization-level practices: (1) organization structures, (2) organization systems, and (3) organization routines. Through learning over time, knowledge becomes transformed through new ways of learning about sustainable practices embedded within structures and systems so that an organization can more effectively respond to its environment through mechanisms for creating, protecting, and transferring sustainable knowledge [83-85]. Consistent with our discussion of leadership capital, we call these sustainable organization practices (see Figure 1). OC exists in relationships that enable an SME to function in a coordinated way. Murray [39] notes that organizational and structural capital are similar contributions to a firm's intellectual capital (IC). OC has been defined as the knowledge that stays within the firm, consisting of organizational routines, procedures, systems, cultures, and databases [85]. Scholars note the importance of developing systems, procedures and routines that support internal organizational functions [86]. These functions promote more efficiency in decision making that empowers employees to achieve organizational goals [87]. Marr [88] suggests that OC includes formal and informal internal practices, virtual networks, and tacit rules, as well as management styles. Generally, at the vanguard of $\mathrm{OC}$ is supportive infrastructures that provide the impetus for innovative sustainable strategies that create greater SME value. Hsu and Wang [45] contend that structural capital refers to processes and procedures that are created by and stored in a firm's technology system that speeds the flow of knowledge. Subramaniam and Youndt [51] discuss the importance of OC in guiding decision making and setting strategic direction. It is the construct of OC that allows IC to be measured and developed, contributing to a firm's competitive advantage [39].

At its most basic, ST-L leaders of SME firms need to develop effective organizational structures and systems (see Figure 1) to accomplish positive environmental outcomes. Structural alignment is required to support the vision and mission of sustainability goals [49]. Epstein et al. [89] notes the challenges when managing social, environmental, and financial performance goals, and that while informal systems promote social relationships, more formal systems are required to measure and reward financial performance. Tideman et al. [23] contend that to be successful, environmental sustainability must be embedded into existing business structures in ways that enable new measurement models to capture sustainable value [23]. Scholars note that this is about finding the balance between economic, social, and environmental solutions [16]. To develop suitable processes and structures, leaders will need to communicate and involve team members [48,69]. Effective team structures should be able to identify and implement desirable change in tasks, outputs or work procedures for the leader's team or work unit [50]. Crews [25] suggests that communication among various stakeholders is critical for environmental reporting, while Epstein [90] and Kantabutra [91] emphasise how the corporate mission and vision statements guide the development of a corporate sustainability strategy. Here, leaders have an influential role as they have the authority and power to establish policies, procedures, and organizational structures, and establish innovative organizational designs [33], that enable more effective integration at both the individual and organizational level [50].

In respect of social and financial consequences, SME leader decisions have implications when driving positive sustainability performance [89]. Benn et al. [55] suggest that task leadership is necessary when complying with legislative requirements, since SME firms are increasingly subject to environmental scrutiny. Organizational routines also translate the work of human capital [92] into positive organizational value. For instance, Stahle [93] notes that capabilities are a learned pattern of collective activity through which the organization 
systematically generates and modifies its operational routines in pursuit of improved efficiencies. Within the absorptive capacity literature, firms who are better at storing knowledge and absorbing new knowledge will be more successful in creating greater value $[29,30]$. Here, absorptive capacity is the ability to learn new routines, recognise new knowledge, assimilate it, and apply it to new ends [29], with a key emergent process being how knowledge is transformed and exploited to create a firm's stock of knowledge. That is, organizational capabilities are reflected in routines that will enable an SME to purposefully create, extend, or modify its resource base [94] through sustainable organization practices. Taken together, we contend that sustainable organization practices will be aggregated at the organization level represented within SME structures, systems, and routines (see Table 1), leading to proposition 2 .

Proposition 2. Leaders of SMES build sustainable organization practices to help embed and distribute knowledge through structures, systems, and routines that support sustainable productivity outcomes.

\subsection{Network Capital, Social Relationship Practices}

Both leadership practices and organization structures and systems work in combination with network capital to help achieve increases in sustainable productivity in SME firms (see Figure 1). Network capital is underscored by two leadership practices: (1) shared co-creation and level of connection, and (2) bonding and linking, trust and commitment. As social relations are built, actors derive benefits from the social structures created, leading to reciprocal benefits $[95,96]$. Such social resources exist as a permanent attribute, in the structure of relations between and among actors [38]. As noted earlier, different leadership practices will need to be established to provide the basis for developing strong social relations. Scholars have noted that sustainability goals are a shared priority, an opportunity for co-creation and connectedness for all interested actors $[10,23,35,64]$. The notion of social capital formation is often called co-creation in the sustainability literature that changes the perspective of social relations from organization-based to value-chain based production processes [35]. Achieving sustainable outcomes is dependent on an integrated network of suppliers, vendors and customers [49]. Here, organizations create robust action in the form of participatory architecture, what Etzion et al. [27] call 'multivocal inscription' and distributed experimentation. On the one hand, participatory architecture considers how to arrange diverse actors to interact and prolong their engagement. On the other hand, inscriptions relate to guidelines, norms and routines that require multi-vocal (or many viewpoints) that become available for different interpretations by multiple actors. For instance, Tolstykh et al. [59] note that in developing ecosystem thinking, it is important to develop co-creation and co-development strategies together, as distinct from an organization-centered innovation approach. They highlight the concept of 'ecosystems' as an exchange of energy in the form of knowledge, information and competencies which is a collaborative process [59]. Achieving sustainable productivity and eco-efficiency outcomes in SMEs requires an integrated effort involving communication between various stakeholders and their communities [25], as well as buy-in from key stakeholders towards establishing sustainable goals $[18,49,53]$. We call this first group of network practices shared co-creation and level of connectedness (see Figure 1).

Developing strong social relations moreover are equally important as individual-level leadership practices. For instance, social relations personify the network relationships forged among actors [96]. Internal networks rely on the linkages established that lead to bonding and linking, whereas external networks refer to the collective practice of a firm that lead to trust and commitment among its external linkages [97-100]. Accordingly, bonding and linking, plus trust and commitment, are the forerunners for achieving shared sustainable goals [18,35]. These include stakeholder influences and expectations $[22,68]$, teamwork [69], networking [36], shared knowledge [10], and shared sustainability goals [35]. Extant scholars take a broader view of stakeholders arguing that all interest groups, par- 
ties, actors, claimants and institutions, who are internal or external actors, are affected by the organization's actions $[45,96]$. Examples include investors, boards of directors, managers, employees, customers, suppliers, competitors, the community and society at large, unions, and governments, where it is the responsibility of top management to ensure that these stakeholders are as satisfied as possible [35,53]. From an SME perspective, this is particularly relevant within supply chain networks and social cooperatives $[100,101]$.

Building on this discussion, Behrendt et al. [65] and Haney et al. [12] draw attention to external leadership activities that are responsible for dealing with environmental issues such as learning, lobbying, and forming alliances, with the aim of solving shared environmental problems. Here, leadership skills related to gathering, analyzing, identifying threats and opportunities, as well as negotiating agreements reinforce the importance of creating and maintaining these networks. The nuances of social capital entails managing a web of relationships that includes social norms, values and obligations that yields potential opportunities for the holders of the capital [35,87,100].

Moreover, several studies reinforce the importance of 'connectedness' between stakeholders to incorporate both short and long-term relationships based on trust, fairness, and collaboration [23,41,98]. Behrendt et al. [65] suggest that effective leaders need to create and maintain a network of relationships with external stakeholders similarly to being attentive to internal stakeholder expectations that mobilize employees around shared organizational goals [22,64]. Costa, Fernandez and Dorrego [102] suggest that the intensity with which the SME firm relates to external entities is a critical source of knowledge that increases SME innovative capabilities. Hence, maintaining commitment with other firms and establishing trust facilitates stakeholder buy-in to the organizational goals and will improve organizational outcomes [49]. Leaders need to be able to influence team members, network with key stakeholders, act as a mentor or coach, and build effective teams $[55,65]$. Consequently, these relationships need to be proactively managed both vertically and horizontally towards achieving sustainable goals [102]. Similarly, exchanging information and developing positive relationships is consistent with sharing a firm's vision and commitment to implementing sustainable capital [25,92] (see Table 1). Taken together, the discussion leads to proposition 3 .

Proposition 3. Building network capital enhances the co-creation and cooperation of SME stakeholders towards achieving sustainable and eco-efficient productivity in SMEs.

\section{Increasing Sustainable Productivity in SMEs}

The significant position of SMEs in the Australian economy also means that they contribute to more than 60 per cent of all carbon dioxide emissions and 70 percent of all pollution [1,28,103]. The Australian Bureau of Statistics [104,105] reports on waste generation by industry and households. The total volume of waste reported in 2018-2019 has increased 10\% to 76 mega tonnes since 2016-2017. In 2016-2017, waste more than doubled to 68.9 mega tonnes, compared with 43.8 mega tonnes reported in 2006-2007 and 22.7 mega tonnes reported in 1996-1997 [104,105]. Australia has a strong dependence on landfill as a form of waste management, which potentially contaminates land, groundwater and air quality, and a hypothetical five percent improvement in efficient use of materials across the Australian economy could benefit Australia's GDP by as much as \$24 billion [105]. With about one fifth of the waste generated originating from households (16.3\% in 2018-2019 and $20 \%$ in 2016-2017), most waste is from the commercial and industrial sector (48.1\%), with the construction sector contributing about $16.8 \%[104,105]$. As such, there is an economic opportunity to see resources recaptured and recirculated within the economy [105]. As the total volume of waste increases due to economic growth, SMEs are experiencing increasing pressure to be more efficient. Consequently, reducing waste and decreasing the use of natural resources has been at the forefront of calls for more sustainable operational practices [27]. Within this context, we next set out to discuss sustainable production and eco-efficiency. 
In building on the discussions in Figure 1, extant research in sustainable production and eco-efficiency has become increasingly popular in recent decades [7,20,70,72]. Scholars suggest that sustainability is about 'doing something' with the environment, which ranges from improving production to reducing an organization's negative environmental impact across all countries [106], often described in terms of eco-efficiency in environmental studies [72,107]. Quinn and Dalton [49] describe sustainability as an organization's commitment to activities that demonstrate the inclusion of environmental concerns in daily business operations. Extant scholars suggest that reducing the use of natural resources such as materials, energy, water, and land mirrors eco-innovations/eco-efficiency in improved products or significantly improved organizational processes $[67,108-111]$.

Increasing sustainable productivity in SMEs (see Figure 1) includes integrating all aspects of an organization's business to include planning, operations, management, and governance [112]. Improved sustainable productivity outcomes reflect the state of SME operational processes, and better resource efficiency, such as recycling and reuse, and reduction in water, energy, and pollution [14,113-115]. According to scholars, sustainable productivity outcomes in SMEs results in a competitive advantage by conserving energy consumption, improved use of materials, and new innovations in products and services [2], including meeting the continuous expectations of corporate sustainability targets [116]. SME leaders are in a powerful position to increase sustainable productivity in their firms. An important strategy to achieve energy and waste efficiency needs to involve SMEs as they are important drivers of economies around the world and collectively their demand for energy is high $[110,117]$. There is increasing interest and strategic concern to reduce and recycle waste, use less energy and water, develop new products or services, and to create efficiencies and increase innovation $[5,6,17,118]$. According to a report by the Organisation for Economic Cooperation and Development (OECD) [117], in comparison with larger firms, fewer SMEs adopt energy efficient practices and leaders often lack adequate skills and resources to improve energy performance. Therefore, increasing energy efficiency represents considerable value for economies [110]. SME practices should increasingly reflect the relationship between eco-efficiency and sustainable productivity given that the former encourages SME firms to 'balance their environmental and economic performances by promoting innovation, growth and competitiveness through sustainable change in business and consumption' [72]. Taken together, efforts of SME managers towards achieving sustainable productivity growth demands new integrative practices of leadership capital (see Table 1), given that increases in sustainability outcomes in SMEs require new models of leadership [12]. The discussion leads to proposition 4.

Proposition 4. ST-L practices are based on achieving sustainable productivity and eco-efficient solutions by focusing on sustainable outcomes (see Figure 1).

\section{Discussion}

Given the importance of leadership to the success or failure of implementing environmentally sustainable business practices, the main contribution of this paper was to classify the emerging leadership skills and knowledge across different knowledge domains necessary to achieve improved SME environmental performance. The authors proposed a new theoretical framework to shed light on the novel connections between several knowledge domains, commencing with leadership skills and knowledge practices (leadership capital), relevant structures, systems, and routines that support organization sustainable practices (organization capital), and social relationship practices such as the importance of shared co-creation, bonding and linking, and trust and commitment (network capital). There are at least three advantages of the theoretical framework presented in Figure 1. First, it integrates for the first time, relevant sustainability leadership practices necessary to build increased sustainable productivity and eco-efficient outcomes in SMEs. Second, it expands relevant sustainability leadership literature by illustrating how this can be classified and partitioned within several knowledge domains. Previously as pointed out, scholars were 
no wiser as to which leadership practices were more germane to a specific knowledge domain, or which leadership practices could be developed by SMEs in pursuing more eco-friendly environmental outcomes. Third, it answers calls in the literature for new models of leadership [12] and addresses the limited studies of leadership practice in small and medium enterprise $[69,119]$.

As a result of this review and the emergent leadership classifications, SMEs will need to adopt new policies and new processes that help support sustainability leadership practices, both at the individual and organizational level. For instance, the paper described the importance of moral and environment practices that leaders need to develop at the organization level, including greater innovation, growth and competitive strategies that drive sustainable change [72]. This is as much about developing structures, systems, and routines in such a way that structural change, e.g., new eco-efficient manufacturing processes, can be embedded and made viable over time. Scholars have been no wiser about what this has looked like prior to this paper. SME leaders will need to adopt a wider lens towards developing routines that encourage co-creation and social relational practices since leaders cannot operate in isolation of other firms across communities. Following Corley and Gioia [120], the theoretical framework also offers a critical repositioning of existing sustainability leadership studies by offering a complementary and intellectual view of leadership practices. The emerging themes in the paper offer a revelatory contribution of existing sustainability leadership knowledge, by altering our understanding of the domains of ST-L practices that reorganize causal maps [121], and how these are connected (Figure 1). Given that scholars have noted that leadership in SMEs represents an ad hoc array of transformational and transactional leadership [76,122], innovational leadership [123], and distributed leadership [124], the theoretical framework presented provides a new way to conceptualize leadership practices within an SME context.

By integrating prior research, it should be noted that, thus far, the role of the 'individual leader in sustainability has received much less focus in the literature than institutional and organizational dimensions' [12], suggesting that leadership issues reflecting sustainable practice is a contemporary issue of our time. While no one leadership approach adequately addresses the nuances of many sustainability approaches [65,122], an intellectual capital approach integrating several sustainable knowledge practices represents a structured way to integrate causal maps, such that future scholars have greater clarity around cause and effect [120]. As such, this review builds on prior research that constitutes a different way of understanding the sustainability leadership literature. Consequently, this review paper has the potential to both improve and advance current research and managerial practice.

The proposed theoretical conceptions offer meaningful insights for SME leaders. From a practical point, for SME leaders, industry bodies, and government, this research is necessary because environmental sustainability impacts small and medium business specifically and broader communities more generally. Currently, there is limited understanding of the key leadership practices needed for SMEs to survive and grow, and there are limited theoretical models to draw upon. We have offered an overview of ST-L by way of an integrated framework. Thus, leaders are provided with a practical approach of how to initiate the types of leadership practices, behaviours and activities that will enhance environmentally sustainable outcomes (ESO) in their firms.

\section{Conclusions}

The theoretical framework presents the first comprehensive integration of the types of leadership practices and knowledge required for positive sustainable productivity in SMEs. The Intellectual Domains of Sustainable Knowledge Practices (Framework) organizes the current literature by synthesizing and clarifying sustainable, environmental and sustainability leadership constructs and provides a new way of thinking about sustainability leadership dimensions. Environmental and economic imperatives make incorporating sustainable productivity outcomes essential, and SMEs will need clear and direct sustainability leadership knowledge to define and implement new business practices, set strategic 
direction, and guide employees towards achieving sustainable productivity in their firms. Thus, knowledge of sustainability leadership practices will assist SME leaders to reduce waste, streamline operations, reduce costs, and develop new products or services, thus reducing their impact on the environment. The framework offers guidance on how to lead and identify areas that are critical in order to achieve eco-efficient outcomes.

\section{Limitations and Future Research}

This review paper has several limitations. First, the conceptual ideas proposed are not tested empirically. Empirical tests of the ideas under each intellectual domain is recommended for future research in relation to SME leadership practices. To our knowledge, this is the first review paper that has attempted to combine the complementarities of the three sustainability leadership approaches while seeking to make clearer connecting intellectual themes. Thus, scholars may find that given the extant literature has tended to treat the three sustainability leadership approaches as separate bodies of knowledge, the proposed intellectual framework offers an opportunity to explore new relationships and causal connections. Future studies might use the classification of leadership practices presented to empirically explore how more eco-efficient outcomes can be achieved in SMEs. For instance, since an ecosystem is a dynamic interactive network of participants for the creation and dissemination of knowledge [59] — what this paper has called network capitalfuture research could explore how the goals of all stakeholders are harmonized when rigid vertical management is absent, and when there is a need to assess the current level of sustainable development of SMEs within a region. Furthermore, future studies might explore the idea of an entrepreneurial ecosystem maturity model as an additional source of leadership practices within an SME context. Another research stream may expand on research regarding financial risk management which is an important part of implementing sustainability practices $[125,126]$, and if managed well, will maintain a higher level of competitiveness and sustainability advantages for SMEs [125]. A useful question to explore in future studies is how community interactions act as a mediating variable influencing the relationships between leadership antecedents and sustainability outcomes in SMEs. Scholars might further explore which of the domains in Figure 1 have a moderating role affecting the strength and weakness of different relationships. Given sustainability within the SME context varies from one country to the next, comparative studies would be particularly useful.

Author Contributions: Conceptualization of this review paper was instigated and modified by J.B., who prepared and wrote the original draft manuscript, forming part of her Ph.D. thesis. Professor P.A.M. was responsible for reviewing this paper, and both authors were responsible for further iterations, reviewing and editing until this final manuscript was produced. P.A.M. supervised this project. Both authors contributed $50 \%$ each to this paper. All authors have read and agreed to the published version of the manuscript.

Funding: This research received no external funding.

Institutional Review Board Statement: Not applicable.

Informed Consent Statement: Not applicable.

Data Availability Statement: Not applicable.

Acknowledgments: We acknowledge the support given by anonymous reviewers.

Conflicts of Interest: The authors declare no conflict of interest.

\section{References}

1. Revell, A.; Stokes, D.; Chen, H. Small Businesses and the Environment: Turning over a New Leaf? Bus. Strategy Environ. 2010, 19, 273-288.

2. Szczepańska-Woszczyna, K.; Kurowska-Pysz, J. Sustainable Business Development Through Leadership in SMEs. Econ. Manag. 2016, 8, 57-69. [CrossRef]

3. Stogdill, R. Leadership, Membership and Organization. Psychol. Bull. 1950, 47, 1. [CrossRef] 
4. McCann, J.; Sweet, M. The Perceptions of Ethical and Sustainable Leadership. J. Bus. Ethics 2014, 121, 373-383. [CrossRef]

5. Laforet, S. Organizational innovation outcomes in SMEs: Effects of age, size, and sector. J. World Bus. 2013, 48, 490-502. [CrossRef]

6. Tomšič, N.; Bojnec, Š.; Simčič, B. Corporate sustainability and economic performance in small and medium sized enterprises. J. Clean. Prod. 2015, 108, 603-612. [CrossRef]

7. Metcalf, L.; Benn, S. Leadership for Sustainability: An Evolution of Leadership Ability. J. Bus. Ethics 2013, 112, 369-384. [CrossRef]

8. Davies, B. Developing Sustainable Leadership; Paul Chapman Publishing: London, UK, 2007.

9. Hargreaves, A.; Fink, D. Sustainable Leadership; Jossey-Bass: San Francisco, CA, USA, 2006.

10. Avery, G.; Bergsteiner, H. Sustainable leadership practices for enhancing business resilience and performance. Strategy Leadersh. 2011, 30, 5-15. [CrossRef]

11. Visser, W.; Courtice, P. Sustainability Leadership: Linking Theory and Practice. In CPSL Report, A Journey of a Thousand Miles: The State of Sustainability Leadership. 2011. Available online: www.cpsl.cam.ac.uk (accessed on 20 June 2016).

12. Haney, A.B.; Pope, J.; Arden, Z. Making it personal: Developing sustainability leaders in business. Organ. Environ. 2020, 33, 155-174. [CrossRef]

13. Wang, X.; Van Wart, M.; Lebredo, N. Sustainability Leadership in a Local Government Context. Public Perform. Manag. Rev. 2014, 37, 339-364. [CrossRef]

14. Aragon-Correa, J.A.; Hurtado-Torres, N.; Sharma, S.; Garcia-Morales, V.J. Environmental strategy and performance in small firms: A resource-based perspective. J. Environ. Manag. 2008, 86, 88-103. [CrossRef]

15. Parker, C.; Redmond, J.; Simpson, M. A review of interventions to encourage SMEs to make environmental improvements. Environ. Plan. 2009, 27, 279-301. [CrossRef]

16. Ferdig, M.A. Sustainability Leadership: Co-creating a Sustainable Future. J. Chang. Manag. 2007, 7, 25-35. [CrossRef]

17. Mahmood, A.; Naveed, R.; Ahmad, N.; Scholz, M.; Khalique, M.; Adnan, M. Unleashing the Barriers to CSR Implementation in the SME Sector of a Developing Economy: A Thematic Analysis Approach. Sustainability 2021, 13, 12710. [CrossRef]

18. Burlea-Schiopoiu, A.; Mihai, L. An Integrated Framework on the Sustainability of SMEs. Sustainability 2019, 11, 6026. [CrossRef]

19. Osagie, E.R.; Wesselink, R.; Blok, V.; Lans, T.; Mulder, M. Individual competencies for corporate social responsibility: A literature and practice perspective. J. Bus. Ethics 2016, 135, 233-252. [CrossRef]

20. Tyler, B.; Lahneman, B.; Beukel, K.; Cerrato, D.; Minciullo, M.; Spielmann, N.; Cruz, A.D. SME Managers' Perceptions of Competitive Pressure and the Adoption of Environmental Practices in Fragmented Industries: A Multi-Country Study in the Wine Industry. Organ. Environ. 2020, 33, 437-463. [CrossRef]

21. Sen, S.; Cowley, J. The relevance of stakeholder theory and social capital theory in the context of CSR in SMEs: An Australian perspective. J. Bus. Ethics 2013, 118, 413-427. [CrossRef]

22. Boiral, O.; Baron, C.; Gunnlaugson, O. Environmental Leadership and Consciousness Development: A Case Study Among Canadian SMEs. J. Bus. Ethics 2014, 123, 363-383. [CrossRef]

23. Tideman, S.G.; Arts, M.C.; Zandee, D.P. Sustainable Leadership. J. Corp. Citizsh. 2013, 49, 17-33.

24. Niu, X.; Wang, X.; Xiao, H. What motivates environmental leadership practise-an empirical analysis in Taiwan. J. Asian Public Policy 2018, 11, 173-187. [CrossRef]

25. Crews, D.E. Strategies for Implementing Sustainability: Five Leadership Challenges. SAM Adv. Manag. J. 2010, 75, 15-21.

26. Svensson, G.; Wood, G. Sustainable leadership ethics: A continuous and iterative process. Leadersh. Organ. Dev. J. 2007, 28, 251-268. [CrossRef]

27. Etzion, D.; Gehman, J.; Ferraro, F.; Avidan, M. Unleashing sustainability transformations through robust action. J. Clean. Prod. 2017, 140, 167-178. [CrossRef]

28. Redmond, J.; Walker, E.; Parker, C.; Simpson, M. Australian SMEs waste to landfill. Australas. J. Environ. Manag. 2014, $21,297-301$. [CrossRef]

29. Cohen, W.; Levinthal, D. Absorptive capacity: A new perspective on learning and innovation. Adm. Sci. Q. 1990, 35, 128-152. [CrossRef]

30. Zahra, S.A.; George, G. Absorptive capacity: A review, reconceptualization, and extension. Acad. Manag. Rev. 2002, 27, 185-203. [CrossRef]

31. Blackman, D. Knowledge Management and Communities of Practice: Supporting Successful Knowledge Transfer. In The Palgrave Handbook of Knowledge Management; Syed, J., Murray, P.A., Hislop, D., Mouzughi, Y., Eds.; Palgrave Macmillan: London, UK, 2018; pp. 227-247.

32. Chiva, R.; Lapiedra, R.; Alegre, J.; Miralles, S. Organizational Learning and Knowledge Management: A Prospective Analysis Based on the Levels of Consciousness. In The Palgrave Handbook of Knowledge Management; Syed, J., Murray, P.A., Hislop, D., Mouzughi, Y., Eds.; Palgrave MacMillan: London, UK, 2018; pp. 227-247.

33. Pertusa-Ortega, E.M.; López-Gamero, M.D.; Pereira-Moliner, J.; Tari, J.-J.; Molina-Azorín, J.F. Antecedents of environmental management: The influence of organizational design and its mediating role between quality management and environmental management. Organ. Environ. 2018, 31, 425-443. [CrossRef]

34. Schein, E. Organizational Culture and Leadership; Jossey-Bass: San Francisco, CA, USA, 1985.

35. Arnold, M. Fostering sustainability by linking co-creation and relationship management concepts. J. Clean. Prod. 2017, 140, 179-188. [CrossRef] 
36. Epstein, M.J.; Buhovac, A.R.; Yuthas, K. Managing Social, Environmental and Financial Performance Simultaneously. Long Range Plan. 2015, 48, 35-45. [CrossRef]

37. Burt, R.S. The contingent value of social capital. Adm. Sci. Q. 1997, 42, 339-365. [CrossRef]

38. Coleman, J.S. Social capital in the creation of human capital. Am. J. Sociol. 1988, 94, S95-S120. [CrossRef]

39. Murray, P.A. The Domains of Intellectual Capital: An Integrative Discourse Across Perspectives. In The Palgrave Handbook of Knowledge Management; Syed, J., Murray, P.A., Hislop, D., Mouzughi, Y., Eds.; Palgrave Macmillan: London, UK, 2018 ; pp. $227-247$.

40. Portes, A. Social capital: Its Origins and applications in modern sociology. Annu. Rev. Sociol. 1998, 24, 1-24. [CrossRef]

41. Adler, P.; Kwon, S. Social capital: Prospects for a new concept. Acad. Manag. Rev. 2002, 27, 17-40. [CrossRef]

42. Reed, K.; Lubatkin, M.; Srinivasan, N. Proposing and Testing an Intellectual Capital-Based View of the Firm. J. Manag. Stud. 2006, 43, 867-893. [CrossRef]

43. Maurer, I.; Ebers, M. Dynamics of social capital and their performance implications: Lessons from biotechnology start-ups. Adm. Sci. Q. 2006, 51, 262-292. [CrossRef]

44. Nahapiet, J.; Ghoshal, S. Social capital, intellectual capital, and the organizational advantage. Acad. Manag. Rev. 1998, 23, 242-266. [CrossRef]

45. Hsu, L.; Wang, C. Clarifying the Effect of Intellectual Capital on performance: The Mediating Role of Dynamic Capability. Br. J. Manag. 2012, 23, 179-205. [CrossRef]

46. Good, J.; Thorpe, A. The nature of organizing: A relational approach to understanding business sustainability. Organ. Environ. 2020, 33, 359-383. [CrossRef]

47. Robertson, J.; Barling, J. Toward a new measure of organizational environmental citizenship practise. J. Bus. Res. 2017, 75, 57-66. [CrossRef]

48. Timmer, D.; Creech, H.; Buckler, C. Becoming a Sustainability Leader. Available online: https://growthorientedsustainableentre preneurship.files.wordpress.com/2016/07/ld-becoming-a-sustainability-leader.pdf (accessed on 2 February 2014).

49. Quinn, L.; Dalton, M. Leading for sustainability: Implementing the tasks of leadership. Corp. Gov. 2009, 9, 21-38. [CrossRef]

50. Yukl, G.; Mahsud, R.; Prussia, G.; Hassan, S. Effectiveness of broad and specific leadership practices. Pers. Rev. 2019, 48, 774-783. [CrossRef]

51. Subramaniam, M.; Youndt, M. The influence of intellectual capital on the types of innovative capabilities. Acad. Manag. J. 2005, 48, 450-463. [CrossRef]

52. Armani, A.; Petrini, M.; Santos, A. What are the Attributes of Sustainable Leadership? R. Bras. Gest. Neg. Sao Paulo 2020, 22, 820-835. [CrossRef]

53. Fry, L.W.; Egel, E. Global Leadership for Sustainability. Sustainability 2021, 13, 6360. [CrossRef]

54. Smith, A.K.; Sarros, J.C. Environmental Leadership: Baseline Surveys and Lessons from Australia's Leaders. Australas. J. Environ. Manag. 2004, 11, 164-176. [CrossRef]

55. Benn, S.; Dunphy, D.; Griffiths, A. Organizational Change for Corporate Sustainability; Routledge, Taylor \& Francis Group: New York, NY, USA, 2014.

56. Strand, R. Strategic Leadership of Corporate Sustainability. J. Bus. Ethics 2014, 123, 687-706. [CrossRef]

57. Egri, C.P.; Herman, S. Leadership in the North American environmental sector: Values, leadership styles, and contexts of environmental leaders and their organizations. Acad. Manag. J. 2000, 43, 571-604. [CrossRef]

58. Burns, H.; Vaught, H.; Bauman, C. Leadership for sustainability: Theoretical foundations and pedagogical practices that foster change. Int. J. Leadersh. Stud. 2015, 9, 131-143.

59. Tolstykh, T.; Gamidullaeva, L.; Shmeleva, N.; Woźniak, M.; Vasin, S. An Assessment of Regional Sustainability via the Maturity Level of Entrepreneurial Ecosystems. J. Open Innov. Technol. Mark. Complex. 2021, 7, 5. [CrossRef]

60. Raffiee, J.A.; Byun, H. Revisiting the portability of performance paradox: Employee mobility and the utilization of human and social capital resources. Acad. Manag. J. 2020, 63, 34-63. [CrossRef]

61. Burns, J. Leadership; Harper \& Row: New York, NY, USA, 1978.

62. Yukl, G.; Gordon, A.; Taber, T. A Hierarchical Taxonomy of Leadership Behaviour: Integrating a Half Century of Behaviour Research. J. Leadersh. Organ. Stud. 2002, 9, 15-32. [CrossRef]

63. Judge, T.; Bono, J. Five-Factor Model of Personality and Transformational Leadership. J. Appl. Psychol. 2000, 85, 751-765. [CrossRef] [PubMed]

64. Jang, Y.; Zheng, T.; Bosselman, R. Top manager's environmental values, leadership, and stakeholder engagement in promoting environmental sustainability in the restaurant industry. Int. J. Hosp. Manag. 2017, 63, 101-111. [CrossRef]

65. Behrendt, P.; Matz, S.; Goritz, A.S. An integrative model of leadership behavior. Leadersh. Q. 2017, 28, 229-244. [CrossRef]

66. Robertson, J.L.; Carleton, E. Uncovering How and When Environmental Leadership Affects Employees' Voluntary Proenvironmental Behavior. J. Leadersh. Organ. Stud. 2018, 25, 197-210. [CrossRef]

67. Prasanna, R.; Upulwehera, J.; Senarath, B.; Abeyrathne, G.; Rajapakshe, P.; Jayasundara, J.; Ekanayake, E.; Gamage, S.K.N. Factors Determining the Competitive Strategic Positions of the SMEs in Asian Developing Nations: Case Study of SMEs in the Agricultural Sector in Sri Lanka. Economies 2021, 9, 193. [CrossRef]

68. Flannery, B.L.; May, D.R. Prominent factors influencing environmental activities: Application of the Environmental Leadership Model (ELM). Leadersh. Q. 1994, 5, 201-221. [CrossRef] 
69. Robinson, D.; Clegg, A. Environmental leadership and competitive advantage through environmental management system standards. Eco-Manag. Audit. 1998, 5, 6-14. [CrossRef]

70. Adams, R.; Jeanrenaud, S.; Bessant, J.; Denyer, D.; Overy, P. Sustainability-oriented Innovation: A Systematic Review. Int. J. Manag. Rev. 2016, 18, 180-205. [CrossRef]

71. Egri, C.P.; Frost, P.J. Leadership for environmental and social change. Leadersh. Q. 1994, 5, 195-200. [CrossRef]

72. Vásquez, J.; Aguirre, S.; Fuquene-Retamoso, C.E.; Bruno, G.; Priarone, P.C.; Settineri, L. A conceptual framework for the eco-efficiency assessment of small- and medium-sized enterprises. J. Clean. Prod. 2019, 237, 117660. [CrossRef]

73. Deinert, A.; Homan, A.C.; Boer, D.; Voelpel, S.C.; Gitermann, D. Transformational leadership sub-dimensions and their link to leaders' personality and performance. Leadersh. Q. 2015, 26, 1095-1120. [CrossRef]

74. Shamir, B.; House, R.J.; Arthur, M. The Motivational Effects of charismatic leadership: A self-concept based theory. Organ. Sci. 1993, 4, 577-594. [CrossRef]

75. Conger, J.A. Charismatic and Transformational Leadership in Organizations: An insider's perspective on these developing streams of research. Leadersh. Q. 1999, 10, 145-179. [CrossRef]

76. Tajasom, A.; Hung, D.K.M.; Nikbin, D.; Hyun, S.S. The role of transformational leadership in innovation performance of Malaysian SMEs. Asian J. Technol. Innov. 2015, 23, 172-188. [CrossRef]

77. Jansen, J.J.P.; Vera, D.; Crossan, M. Strategic leadership for exploration and exploitation: The moderating role of environmental dynamism. Leadersh. Q. 2009, 20, 5-18. [CrossRef]

78. Kurucz, E.; Colbert, B.; Ludeke-Freund, F.; Upward, A. Relational leadership for strategic sustainability: Practices and capability to advance the design and assessment of sustainable business models. J. Clean. Prod. 2017, 140, 189-204. [CrossRef]

79. Van Velsor, E.; McCauley, C.D. The Center for Creative Leadership Handbook of Leadership Development, 2nd ed.; Jossey-Bass: San Francisco, CA, USA, 2004.

80. Battilana, J.; Gilmartin, M.; Sengul, M.; Pache, A.-C.; Alexander, J.A. Leadership competencies for implementing planned organizational change. Leadersh. Q. 2010, 21, 422-438. [CrossRef]

81. Boal, K.B.; Hooijberg, R. Strategic leadership research: Moving on. Leadersh. Q. 2000, 11, 515-550. [CrossRef]

82. Carro-Suárez, J.; Sarmiento-Paredes, S.; Rosano-Ortega, G. Organizational culture and its influence in business sustainability. The importance of culture in corporate sustainability [La cultura organizacional y su influencia en la sustentabilidad empresarial. La importancia de la cultura en la sustentabilidad empresarial], in Spanish. Estud. Gerenc. 2017, 33, 352-365. [CrossRef]

83. Arora, A.; Nandkumar, A. Insecure Advantage? Markets for Technology and the Value of Resources for Entrepreneurial Ventures. Strateg. Manag. J. 2012, 33, 231-251.

84. Hu, L.; Randel, A.E. Knowledge Sharing in Teams, Social Capital, Extrinsic Incentives and Team Innovation. Group Organ. Manag. 2014, 39, 213-243. [CrossRef]

85. Bontis, N.; Fitz-enz, J. Intellectual capital ROI: A causal map of human capital antecedents and consequents. J. Intellect. Cap. 2002, 3, 223-247. [CrossRef]

86. Cohen, S.; Kaimenakis, N. Intellectual capital and corporate performance in knowledge-intensive SMEs. Learn. Organ. 2007, 14, 241-262. [CrossRef]

87. Clarke, C.; Seng, D.; Whiting, R. Intellectual capital and firm performance in Australia. J. Intellect. Cap. 2011, 12, 505-530. [CrossRef]

88. Marr, B. Measuring and benchmarking intellectual capital. Benchmarking Int. J. 2004, 11, 559-570. [CrossRef]

89. Epstein, M.J.; Buhovac, A.R.; Yuthas, K. Implementing Sustainability: The role of leadership and organizational culture. Strateg. Financ. 2010, 91, 41-47.

90. Epstein, M.J. Making Sustainability Work; Greenleaf Publishing Limited: Sheffield, UK, 2008.

91. Kantabutra, S. Toward an Organizational Theory of Sustainability Vision. Sustainability 2020, 12, 1125. [CrossRef]

92. Johnson, W.H. An integrative taxonomy of intellectual capital: Measuring the stock and flow of intellectual capital components in the firm. Int. J. Technol. Manag. 1999, 18, 562-575. [CrossRef]

93. Stahle, P. Understanding dynamics of intellectual capital of nations. J. Intellect. Cap. 2008, 9, 164-177. [CrossRef]

94. Helfat, C.E. Know-how and asset complementarities and dynamic capability accumulation: The case of R\&D. Strateg. Manag. J 1997, 18, 339-360.

95. Baker, W.E. Market networks and corporate behavior. Am. J. Sociol. 1990, 96, 589-625. [CrossRef]

96. Pillai, K.G.; Hodgkinson, G.P.; Kalyanaram, G.; Nair, S.R. The negative effects of social capital in organizations: A review and extension. Int. J. Manag. Rev. 2017, 19, 97-124. [CrossRef]

97. Redondo, M.; Camarero, C. Social Capital in University Business Incubators: Dimensions, antecedents and outcomes. Int. Entrep. Manag. J. 2019, 15, 599-624. [CrossRef]

98. Manning, P. Explaining and developing social capital for knowledge management purposes. J. Knowl. Manag. 2010, 14, 83-99. [CrossRef]

99. Wang, L.; Cotton, R. Beyond Moneyball to social capital inside and out: The value of differentiated workforce experience ties to performance. Hum. Resour. Manag. 2018, 57, 761-780. [CrossRef]

100. Bontis, N.; Ciambotti, M.; Palazzi, F.; Sgro, F. Intellectual capital and financial performance in social cooperative enterprises. J. Intellect. Cap. 2018, 19, 712-731. [CrossRef] 
101. Whipple, J.M.; Wiedmer, R.; Boyer, K.K. A dyadic investigation of collaborative competence, social capital, and performance in buyer-supplier relationships. J. Supply Chain Manag. 2015, 51, 3-21. [CrossRef]

102. Costa, R.; Fernandez, F.; Dorrego, P. Critical elements for product innovation at Portuguese innovative SMEs: An intellectual capital perspective. Knowl. Manag. Res. Pract. 2014, 12, 322-338. [CrossRef]

103. Wiesner, R.; Chadee, D.; Best, P. Managing Change Toward Environmental Sustainability: A Conceptual Model in Small and Medium Enterprises. Organ. Environ. 2017, 31, 152-177.

104. Australian Bureau of Statistics (2018-2019) Waste Account, Australia, Experimental Estimates. Available online: https://www.abs gov.au/statistics/environment/environmental-management/waste-account-australia-experimental-estimates/2018-19 (accessed on 15 March 2020).

105. Australian Bureau of Statistics (2016-2017) Waste Account, Australia, Experimental Estimates. Available online: https:/ / www.abs. gov.au/statistics/environment/environmental-management/waste-account-australia-experimental-estimates/2016-17 (accessed on 20 April 2018).

106. Bos-Brouwers, H. Corporate Sustainability and Innovation in SMEs: Evidence of Themes and Activities in Practice. Bus. Strategy Environ. 2009, 19, 417-435. [CrossRef]

107. Heikkurinen, P.; Young, C.W.; Morgan, E. Business for sustainable change: Extending eco-efficiency and eco-sufficiency strategies to consumers. J. Clean. Prod. 2019, 218, 656-664. [CrossRef]

108. Hojnik, J.; Ruzzier, M. What drives eco-innovation? A review of an emerging literature. Environ. Innov. Soc. Transit. 2016, 19, 31-41. [CrossRef]

109. Klewitz, J.; Hansen, E.G. Sustainability-oriented innovation of SMEs: A systematic review. J. Clean. Prod. 2014, 65, 57-75. [CrossRef]

110. Henriques, J.; Catarino, J. Motivating towards energy efficiency in small and medium enterprises. J. Clean. Prod. 2016, 139, 42-50. [CrossRef]

111. Hart, S. A Natural-Resource-Based view of the Firm. Acad. Manag. Rev. 1995, 20, 986-1014. [CrossRef]

112. Goodland, R. The urgent need for ecosystem integrity and ethics to support environmental sustainability. Glob. Bioeth. 1998, 11, 29-46. [CrossRef]

113. Farrell, A.; Hart, M. What Does Sustainability Really Mean? The Search for Useful Indicators. Environ. Sci. Policy Sustain. Dev. 1998, 40, 4-31. [CrossRef]

114. Gimenez, C.; Sierra, V.; Rodon, J. Sustainable operations: Their impact on the triple bottom line. Int. J. Prod. Econ. 2012, 140, 149-159. [CrossRef]

115. Sroufe, R. Integration and organizational change towards sustainability. J. Clean. Prod. 2017, 162, 315-329. [CrossRef]

116. Meuer, J.; Koelbel, J.; Hoffmann, V.H. On the nature of corporate sustainability. Organ. Environ. 2020, 33, 310-341. [CrossRef]

117. OECD. Small, Medium, Strong: Trends in SME Performance and Business Conditions; Retrieved from Paris; OECD Publishing: Paris, France, 2017.

118. Green, D.D.; McCann, J. Benchmarking a leadership model for the green economy. Benchmarking Int. J. 2011, 18, 445-465. [CrossRef]

119. Uhlaner, L.; Berent-Braun, M.; Jeurissen, R.; Wit, G. Beyond Size: Predicting Engagement in Environmental Management Practices of Dutch SMEs. J. Bus. Ethics 2012, 109, 411-429. [CrossRef]

120. Corley, K.G.; Gioia, D.A. Building theory about theory building: What constitutes a theoretical contribution? Acad. Manag. Rev. 2011, 36, 12-32. [CrossRef]

121. Whetten, D.A. What constitutes a theoretical contribution? Acad. Manag. Rev. 1989, 14, 490-495. [CrossRef]

122. Franco, M.; Matos, P.G. Leadership styles in SMEs: A mixed-method approach. Int. Entrep. Manag. J. 2015, 11, 425-451. [CrossRef]

123. McAdam, R.; Moffett, S.; Hazlatt, S.; Shevlin, M. Developing a model of innovation implementation for UK SMEs: A path analysis and explanatory case analysis. Int. Small Bus. J. 2010, 28, 195-214. [CrossRef]

124. Cope, J.; Kempster, S.; Parry, K. Exploring Distributed Leadership in the Small Business Context. Int. J. Manag. Rev. 2011, 13, 270-285. [CrossRef]

125. Olah, J.; Kovacs, S.; Virglerova, Z.; Lakner, Z.; Kovacova, M.; Popp, J. Analysis and Comparison of Economic and Financial Risk Sources in SMEs of the Visegrad Group and Servia. Sustainability 2019, 11, 1853. [CrossRef]

126. Olah, J.; Virglerova, Z.; Popp, J.; Kliestikova, J.; Kovacs, S. The Assessment of Non-Financial Risk Sources of SMEs in the V4 Counties and Serbia. Sustainability 2019, 11, 4806. [CrossRef] 